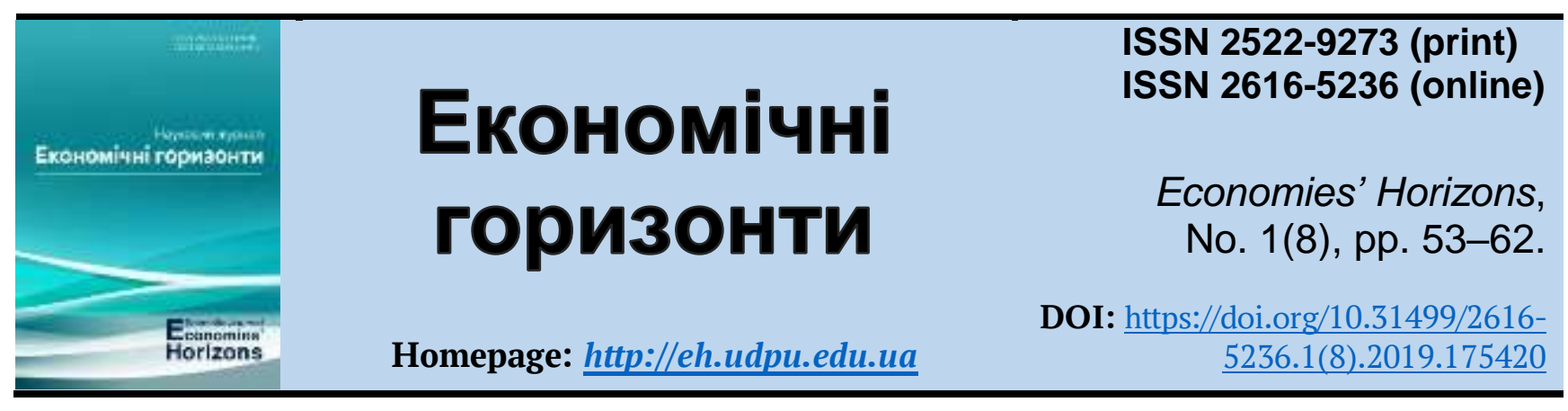

UDC 368.5(477)

\title{
Insurance of agricultural products with state support in Ukraine: state, problems and prospects of development
}

\author{
Liudmyla A. Chvertko ${ }^{1}$, Cand. Ec. Sc., Associate Professor \\ Oksana A. Vinnytska² ${ }^{2}$ Cand. Ec. Sc., Associate Professor \\ Tetiana O. Korniienko ${ }^{3}$, Cand. Ec. Sc.
}

Received: 13 March 2019

Accepted: 14 April 2019
Chvertko, L. A., Vinnytska, O. A. and Korniienko, T. O. (2019), "Insurance of agricultural products with state support in Ukraine: state, problems and prospects of development", Economies' Horizons, no. 1(8), pp. 53-62, doi: https://doi.org/10.31499/2616$\underline{5236.1(8) .2019 .175420 .}$.

\begin{abstract}
The purpose of the research is to substantiate the laws of development of agricultural insurance with state support in Ukraine, and provide a set of practical recommendations for implementation of insurance mechanisms for financial support of agriculture. Methodology. The theoretical and methodological basis of the research are the dialectical method of knowledge of economic processes, the fundamental provisions of modern economic theory, scientific works domestic and foreign scientists on economic relations between participants of the agricultural insurance market with state support for agricultural products. A systematic approach, methods of generalization, induction, deduction, analysis, synthesis and comparison were used to achieve this purpose. Results. The necessity and importance of using insurance mechanisms to mitigate risks for agricultural producers had been determined. The state of economic relations for the protection of property interests of agricultural producers had been reviewed in general, and trends in the development of subsidized crop insurance in the insurance market of Ukraine had been identified. The indicators of agricultural insurance and the amount of subsidies from the state budget allocated to reduce the cost of insurance premiums (contributions), which actually had been paid by actors of the agricultural market, had been analyzed. It was revealed that in 2005-2008 the introduction of state support for crop insurance had a positive impact on the performance of the agricultural insurance market, contributed to the popularization of this type of insurance in Ukraine, and positively affected protecting the interests of agricultural producers. The factors hindering the development of domestic crop insurance with state support were revealed. It had been proved that current level of penetration of this kind of insurance protection remains low and insufficient to guarantee the safety of
\end{abstract}

${ }^{1}$ Pavlo Tychyna Uman State Pedagogical University; Associate Professor at the Department of Finance, Accounting and Economic Security; ORCID ID: https://orcid.org/0000-0003-2788-6991; e-mail: ludaum@ukr.net.

${ }^{2}$ Pavlo Tychyna Uman State Pedagogical University; Associate Professor at the Department of Finance, Accounting and Economic Security; ORCID ID: https://orcid.org/0000-0001-6402-6451; e-mail: vinnytska.oksana@ukr.net.

${ }_{3}$ Pavlo Tychyna Uman State Pedagogical University; Associate Professor at the Department of Finance, Accounting and Economic Security; ORCID ID: https://orcid.org/0000-0001-8020-0771; e-mail: kornienkoto@ukr.net. 
business activities in the agricultural sector, the current model of agricultural state aid, provided by the Law of Ukraine "On peculiarities of crop insurance with state support", was inefficient and therefore required reformation. The importance of improvements in state regulation, including implementation mechanisms of the existing legislation, and state policy of financial support had been substantiated. It was determined that the market model of crop insurance system in Ukraine should be based on the principles of public-private partnership. Practical meaning appears in the possibility of using theoretical conclusions and practical recommendations for the further development of agricultural insurance in general and crop insurance with state support in particular. Prospects for further research are identification and scientific substantiation of the ways of forming a reliable mechanism for insurance protection of property interests of agricultural producers, development and legislation of recommendations on the forms of effective interaction between the main participants in agricultural insurance - agricultural producers, insurance companies and government.

Keywords: agriculture, agricultural producers, agricultural insurance, agricultural risk management, crop insurance, subsidized insurance, insurance premium, compensation of insurance payments, insured crop acreage.

JEL Classification: D 81, G 22, K 39, O 13, Q 14.

Number of references: 16; number of tables: 1; number of figures: 2; number of formulas: $\mathbf{0 .}$

\title{
Страхування сільськогосподарської продукції з державною підтримкою в Україні: стан, проблеми та перспективи розвитку
}

\author{
Л. А. Чвертко ${ }^{1}$, к. е. н., доцент
}

О. А. Вінницька ${ }^{2}$, к. е. н., доцент

Т. О. Корнієнко ${ }^{3}$, к. е. н.

Стаття надійшла: 13.03.2019

Стаття прийнята: 14.04.2019
Chvertko, L. A., Vinnytska, O. A., Korniienko, T. O. Insurance of agricultural products with state support in Ukraine: state, problems and prospects of development. Економічні горизонти. 2019. № 1(8). C. 53-62. DOI: 10.31499/2616-5236.1(8).2019.175420.

Анотація. Мета дослідження. Метою дослідження є обгрунтування закономірностей розвитку страхування сільськогосподарської продукції з державною підтримкою в Україні, а також розробка практичних рекомендацій щодо реалізації страхових механізмів фінансової підтримки сільського господарства. Методологія. Теоретико-методичною основою дослідження $\epsilon$ діалектичний метод пізнання економічних процесів, фундаментальні положення сучасної економічної теорії, теорії фінансів і страхування, наукові праці вітчизняних і зарубіжних учених щодо дослідження сутності та змісту економічних відносин між учасниками ринку агрострахування, зокрема, ринку страхування сільськогосподарської продукції 3 державною підтримкою. Для досягнення поставленої мети використано системний підхід, методи узагальнення, індукції, дедукції, аналізу, синтезу та порівняння. Результати. Визначено необхідність та значення використання страхових механізмів для мінімізації ризиків

\footnotetext{
${ }^{1}$ Уманський держсавний педагогічний університет імені Павла Тичини; доцент кафедри фінансів, обліку та економічної безпеки; ідентифікатор ORCID: https://orcid.org/0000-0003-2788-6991; e-mail: ludaum@ukr.net.

${ }^{2}$ Уманський держсавний педагогічний університет імені Павла Тичини; доцент кафедри фінансів, обліку та економічної безпеки; ідентифікатор ORCID: https://orcid.org/0000-0001-6402-6451; e-mail: vinnytska.oksana@ukr.net.

${ }^{3}$ Уманський держсавний педагогічний університет імені Павла Тичини; доцент кафедри фінансів, обліку та економічної безпеки; ідентифікатор ORCID: https://orcid.org/0000-0001-8020-0771; e-mail:kornienkoto@ukr.net.
} 
сільськогосподарських товаровиробників. Оцінено стан економічних відносин щодо захисту майнових інтересів агровиробників в цілому та визначено тенденції розвитку субсидованого страхування сільськогосподарських культур на страховому ринку України. Здійснено аналіз показників розвитку агрострахування та обсягів субсидій 3 держбюджету, виділених для здешевлення вартості страхових премій (внесків) фактично сплачених суб'єктами аграрного ринку. Встановлено, що запровадження у 2005-2008 рр. державної підтримки страхування сільськогосподарської продукції мало позитивний вплив на показники функціонування ринку сільськогосподарського страхування, сприяло популяризації цього виду страхування в Україні та відіграло позитивну роль у захисті інтересів аграріїв. Виявлено чинники, які стримують розвиток вітчизняного страхування сільськогосподарської продукції з державною підтримкою. Доведено, що на сьогодні рівень проникнення цього виду страхового захисту залишається низьким i недостатнім для гарантування безпеки підприємницької діяльності в аграрному секторі економіки, а сучасна модель державної допомоги сільськогосподарським товаровиробникам, передбачена Законом України «Про особливості страхування сільськогосподарської продукції 3 державної підтримкою», $\epsilon$ неефективною та потребує реформування. Обгрунтовано необхідність удосконалення державного регулювання, в тому числі й щодо механізмів виконання чинних нормативно-правових актів, та системної фінансової підтримки з боку держави. Визначено, що ринкова модель розвитку системи страхування сільськогосподарської продукції в Україні має базуватися на засадах державно-приватного партнерства. Практичне значення виявляється в можливості використання теоретичних висновків і практичних рекомендацій для подальшого розвитку аграрного страхування в цілому та страхування сільськогосподарської продукції 3 державною підтримкою, зокрема. Перспективи подальщих досліджень полягають у визначенні та науковому обгрунтуванні шляхів формування надійного механізму страхового захисту майнових інтересів виробників сільськогосподарської продукції, розробці та законодавчому оформленні рекомендацій щодо форм ефективної взаємодії головних учасників аграрного страхування - сільськогосподарських товаровиробників, страхових компаній та уряду.

Ключові слова: сільське господарство, сільськогосподарські товаровиробники, сільськогосподарське страхування, агрострахування, механізм управління ризиками в сільському господарстві, страхування сільськогосподарської продукції, субсидоване страхування, страхова премія, компенсація вартості страхових платежів, площа застрахованих посівів.

Кількість джерел: 16; кількість таблиць: 1; кількість рисунків: 2; кількість формул: 0.

\section{Introduction.}

Crisis phenomena in the economy and political instability negatively affect the results of the functioning of the Ukrainian agrarian sector. Along with the permanent disposal of fixed assets, reduction of cultivation of agricultural crops, the agricultural producers faced the problem of providing own production with the required amount of financial resources. At the same time, the results of the management of agricultural enterprises are largely determined by seasonality of production, dependence on weather and climatic conditions and the action of a number of other factors, the impact of which in many cases can not be controlled. As a result, with each passing year, the danger of direct material losses or failure to achieve the desired result (income, profit) increases for agricultural producers.

The high level of agricultural production risks in Ukraine necessitates the search for effective management tools for them. Insurance is widely used to ensure the stability of agricultural development in economically developed countries.

\section{Literature review.}

Problems of the use of insurance mechanisms for the protection of property interests of agricultural producers are highlighted in the writings of such scholars as Yu. Aleskerova 
(2014), M. Bondarchuk and I. Kondrat (2014), N. Dobizha (2013), V. Shebanin and Yu. Kormyshkin (2018), O. Lobova (2010), Yu. Melnychuk and M. Slatvinskyi (2018), X. Marych (2017), T. Petruk (2017) and others. However, to date, the development of agricultural risk insurance to ensure the sustainable development of this sector remains unresolved and requires further research.

\section{Methods.}

The theoretical and methodological basis of the research is the dialectical method of knowledge of economic processes, the fundamental provisions of modern economic theory, the theory of finance and insurance, the scientific works of domestic and foreign scientists on the study of the essence and content of economic relations between market participants of agro-insurance, in particular, the market of insurance of agricultural products with the state support. To achieve the goal, a systematic approach, methods of generalization, induction, deduction, analysis, synthesis and comparison are used.

\section{Research objectives.}

The purpose of the study is to substantiate the laws of development of insurance of agricultural products with state support in Ukraine, as well as to develop practical suggestions on the prospects of implementation of insurance mechanisms for financial support of agriculture.

\section{Results and discussions.}

Agriculture is an important sphere of economic activity, the task of which is the production of agricultural products, providing the population with food and raw materials for a number of industries. The associate membership of Ukraine in the European Union and the substantial financial support of the agrarian sector of the EU member states within the framework of the common agricultural policy lead to the search for effective mechanisms for supporting Ukrainian agricultural producers to ensure their competitiveness on the European and world markets. An important component of the economic mechanism of functioning of agriculture which is of exceptional importance for its sustainable development, is the system of insurance relations.

When stability and welfare of the country reaches a certain level, both workers and employers begin to think about their future, provide their old age, finance the risks that exist in every person's life. The basis for the implementation of insurance activities is the legal framework and its organization elements. An important scientific approach to the analysis of insurance activity is the analysis of the development of legislation on insurance in Ukraine. Without studying organizational and legal provision it is impossible to give a general objective of characterizing the insurance (Melnychuk and Slatvinskyi, 2018, pp. 55-64).

The growing interest in agricultural insurance risks in Ukraine since 2001 is a logical consequence of an increase in agricultural output. Agricultural enterprises began to increase investment in production, the sector became interesting for Ukrainian and international business. However, to date, the state of relations for the protection of property interests of producers, characterized by slowness and complexity of development and needs the state support.

Certain positive changes in the field of agri-insurance took place only after the 2004 Law of Ukraine No. 1877-IV (The Verkhovna Rada of Ukraine, 2004), which provided the compensation from the state budget of some insurance premiums paid by agricultural producers under insurance contracts. In particular, during 2005-2008 in the state budget, each year, funds were put up to reduce the cost of insurance premiums (contributions) actually paid by the subjects of the agrarian market the state compensated farmers who insured their crops, $50 \%$ of the insurance premium and $50 \%$ of the franchise in payment. However, in the future, the situation in the field of agri-insurance remained complicated and did not meet the declared aspirations. It was planned to allocate 54 million UAH from the state budget for the needs of subsidized insurance of agricultural crops, instead, as a result of amendments to the budget painting, these 
Chvertko, L. A., Vinnytska, O. A., Korniienko, T. O. Insurance of agricultural products with state support in Ukraine: state, problems and prospects of development

expenses were reduced by 48.1 million $\mathrm{UAH}$ (Accounting Chamber of Ukraine, 2006). Only 934 subjects of the agrarian market benefited from financial support for the reduction of the cost of insurance premiums, which covered 390.6 thousand hectares, which is $6.4 \%$ of the area planted with winter crops for the 2006 harvest (Liga: Zakon, 2006) The volume of actually paid insurance premiums by the subjects of the agrarian market amounted to UAH 12.8 million, of which UAH 5.84 million (Table 1) was reimbursed from the state budget.

Table 1. The indicators of crop insurance in Ukraine in 2005-2017

\begin{tabular}{|c|c|c|c|c|c|c|c|c|c|c|}
\hline Years & 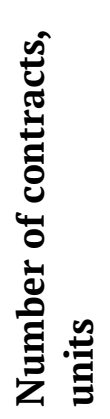 & 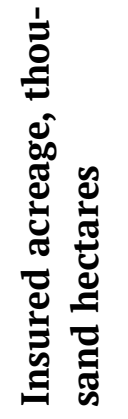 & 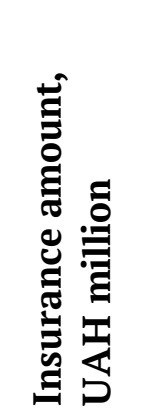 & 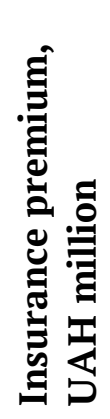 & 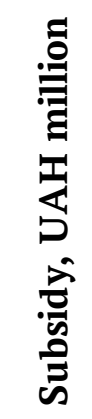 & 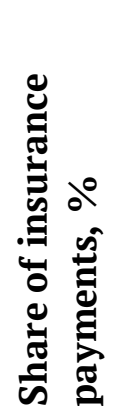 & 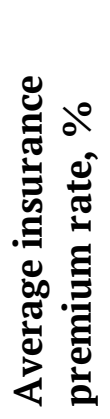 & 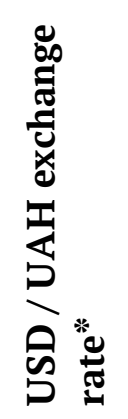 & 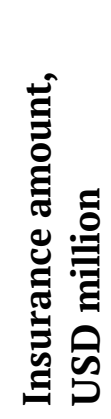 & 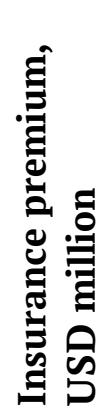 \\
\hline 2005 & 910 & 390 & 337.3 & 12.8 & 5.8 & 26.2 & 3.8 & 5.05 & 66.8 & 2.5 \\
\hline 2006 & 1330 & 670 & 616.7 & 28.5 & 12.5 & 9.2 & $\mathrm{n} / \mathrm{d}$ & 5.05 & 122.1 & 5.6 \\
\hline 2007 & 4397 & 2360 & 2593.2 & 116.7 & 47.8 & 21.4 & 4.5 & 5.05 & 513.5 & 23.1 \\
\hline 2008 & 1637 & 1171 & 3153.4 & 155.4 & 72.8 & 3.8 & 4.9 & 5.22 & 604.1 & 29.8 \\
\hline 2009 & 1980 & 510 & 1300.0 & 42.0 & 0 & 36.5 & 3.2 & 8.00 & 162.5 & 5.3 \\
\hline 2010 & 1217 & 553 & 2455.0 & 72.1 & 0 & 50.9 & 3.8 & 7.91 & 310.4 & 9.1 \\
\hline 2011 & 2710 & 786 & 3640.0 & 136.3 & 0 & 28.0 & 3.7 & 7.98 & 456.1 & 17.1 \\
\hline 2012 & 1936 & 727 & 3463.0 & 130.4 & 0.09 & 41.0 & 3.8 & 7.99 & 433.4 & 16.3 \\
\hline 2013 & 1722 & 869 & 4395.0 & 135.4 & 0 & 9.7 & 3.1 & 7.99 & 550.1 & 16.9 \\
\hline 2014 & 1392 & 732 & 3055.0 & 72.8 & 0 & 7.6 & 2.4 & 12.95 & 235.9 & 5.6 \\
\hline 2015 & 1062 & 689 & 3969.0 & 77.7 & 0 & 12.9 & 2.0 & 22.91 & 173.3 & 3.4 \\
\hline 2016 & 793 & 700 & 6240.0 & 157.0 & 0 & 44.2 & 2.5 & 26.02 & 239.8 & 6.0 \\
\hline 2017 & 957 & 661 & 5933.0 & 204.3 & 0 & 4.9 & 3.4 & 26.54 & 223.5 & 7.7 \\
\hline
\end{tabular}

* US Dollar / Ukraine Hryvnia official exchange rate at the end of each year.

Source: Developed by (Agrarian Union of Ukraine, 2018).

According to studies, 2006 was marked by an increase in interest in agrarian insurance both among insurers and policyholders. Evidence for this is the increase in the number of insurance companies that participated in the subsidized program of crop insurance by $32.1 \%$, the number of insurance contracts by $46.2 \%$, the volume of insured areas by $71.8 \%$. In general, 12.52 millions UAH were used in 2006 for state support for the implementation of insurance programs and guaranteeing the income of agricultural producers.

The volume of state support in 2007 has increased to 47.82 million UAH (from the state budget of Ukraine 50 million UAH). At the same time the insurers having concluded 4397 agreements on the insurance of crop crops, received 117.12 million UAH premiums, which exceeds the equivalent of the previous year by more than 4 times. The total surface area of insured persons under the subsidized insurance program has increased to $9.1 \%$.

In 2008, according to the budget inscriptions for partial compensation of the cost of insurance payments actually paid by agricultural producers, it was intended to allocate about 
200 million UAH, but due to lack of state funds was allocated 72.8 million UAH. Correspondingly, the indicators of the development of the market of agri-insurance also decreased. Thus, for this year more than half of the volume of the insured sown area has decreased, almost $63 \%$ - the number of insurance contracts. The growth of the volume of insurance premiums (in 1.3 times) was due to an increase from $4.5 \%$ to $4.9 \%$ of the average tariff rate and the value of the sum insured (1.2 times).

The assessment of the development of the agricultural insurance market in Ukraine in 2005-2008 showed significant differences in the rates of premiums and sums of premiums per unit of the insured area under the agreements. For example, in 2006 the amount of the premium for $1 \mathrm{~h}$ of wheat insurance in the Donetsk region. amounted to $18.5 \mathrm{UAH}$, and in Poltava region - 169.9 UAH. The sum of the insurance premium for 1 hectare less than 30 UAH was recorded in 11 regions. Such fluctuations, in terms of experts, can not be explained by risk maps or relevant loss data for previous periods of management. Obviously, at the tariff rates of $0.1-0.5 \%$, insurance companies insured crops formally, most likely, when insuring mortgaged property or for other reasons.
In addition, a significant problem encountered by market participants under the program of subsidized insurance of crops, was ill-conceived administration. The subsidies were distributed through the district agriculture departments which led to the need for additional incentives for officials to receive the appropriate subsidy. No less difficult was the fact that compensation for the cost of insurance premiums was paid to policyholders after the conclusion of insurance contracts. That is, the insured should have withdrawn from the circulation the entire amount of the insurance premium and received compensation only in a few months. This practice has prevented many agricultural producers from insuring agricultural products, because insurance proved to be too expensive for them.

At the same time it is indisputable that the introduction of state support for agricultural insurance in 2005-2008, despite all its opacity, inefficiency and expenditure for agricultural producers, generally contributed to the popularization of this type of insurance in Ukraine and played a positive role in protecting the interests of farmers. During all subsequent years, the agribusiness development indicators did not exceed the values of this period (Fig. 1).

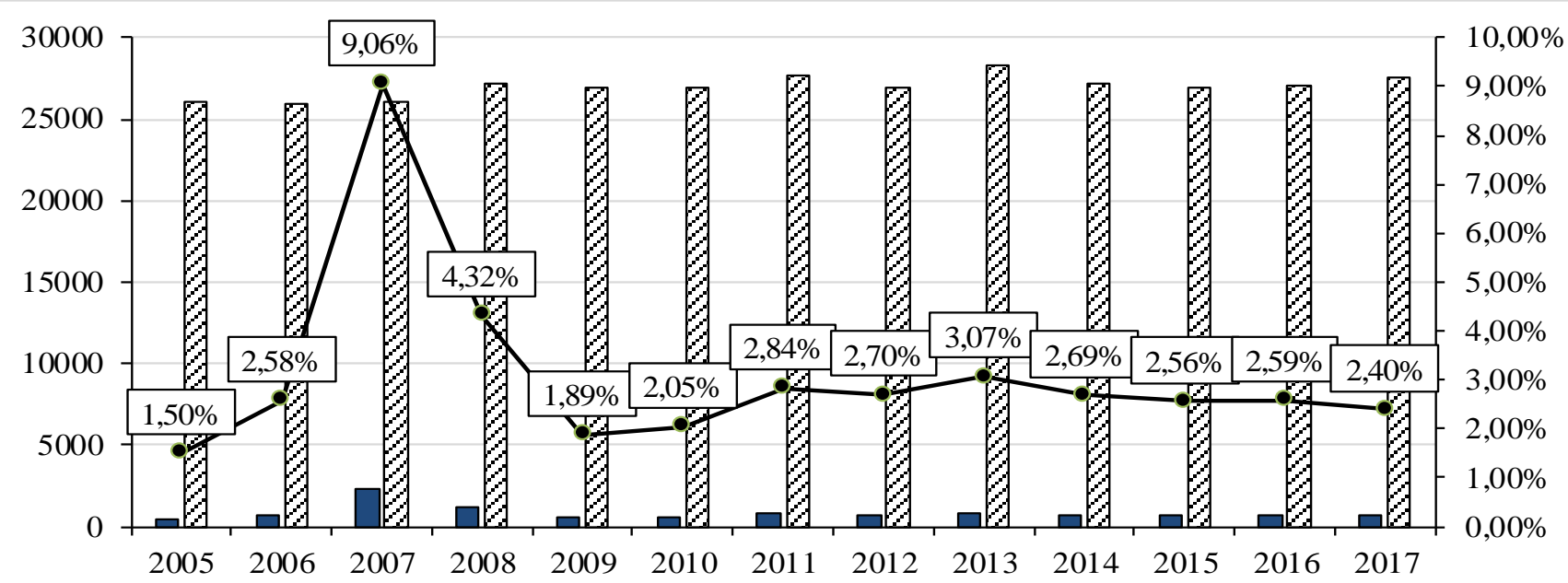

$\square$ Insured crop acreage, thousand hectares $\mathscr{C}$ Crop acreage, thousand hectares

-—-Insured share of crop acreage, \%

Fig. 1. The dynamics of insured crop acreage in Ukraine in 2005-2017

Source: developed by (Agrarian Union of Ukraine, 2018). 
The unstable economic situation in the country and the lack of budget funds to compensate insurers for the cost of insurance payments, which was marked in 2009 , have negatively affected the indicators of the functioning of the agricultural insurance market. The abolition of subsidies led to a sharp decrease in the volume of insurance revenues: 3.7 times compared to 2008, and the area of insured crops decreased by more than 4.6 times during 2008-2009: from 2360 thousand hectares in 2007 to 510 thousand hectares in 2009 . Since 2010 this market has stabilized again and began to grow slowly until 2014, as evidenced by the dynamics of insurance premiums in dollar terms, presented in Fig. 2.

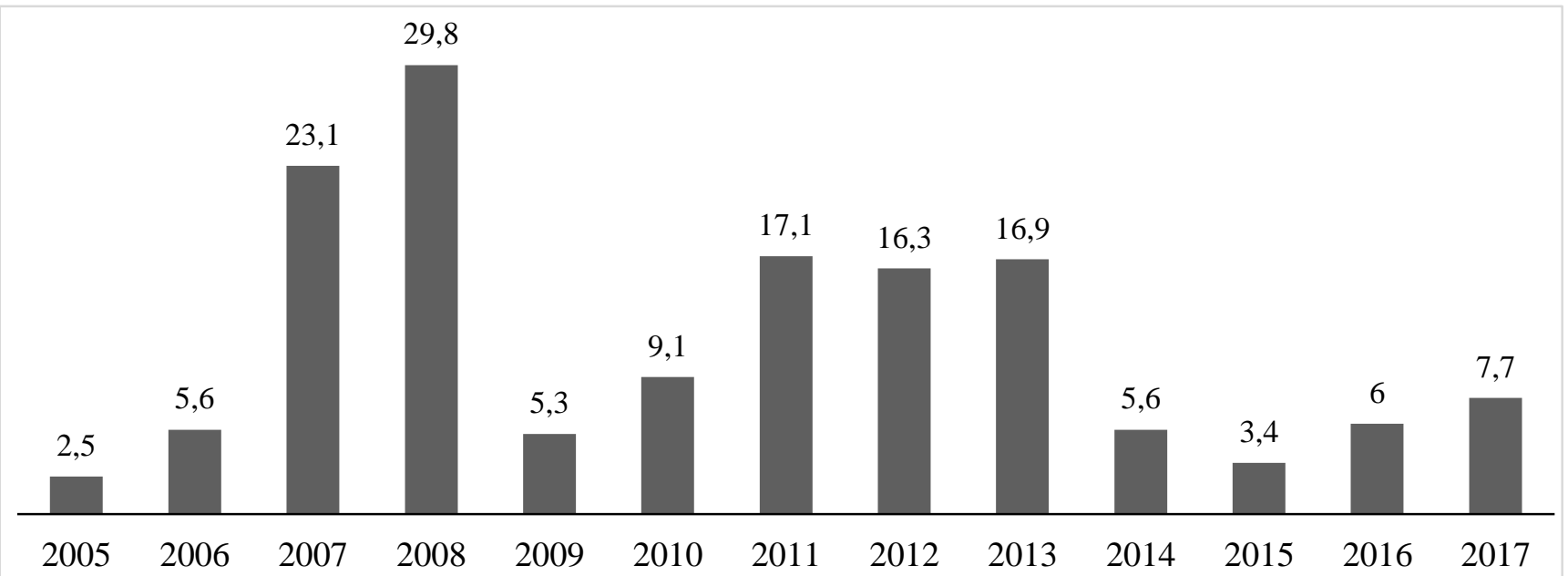

Fig. 2. The dynamics of crop insurance premiums in Ukraine in 2005-2017, million USD Source: developed by (Agrarian Union of Ukraine, 2018).

In order to ensure the development and efficiency of the agricultural risk insurance system in 2012, the Law of Ukraine "On the Features of Insurance of Agricultural Products with State Support" was adopted (The Verkhovna Rada of Ukraine, 2012): a separate license was introduced for the insurance activity in the form of voluntary insurance of agricultural products, a number of insurance products have been developed that can be used as standard products to improve the market. In accordance with this legislative act, the subjects of relations of insurance of agricultural products with state support are defined: insurers who have received a corresponding license and meet the requirements of this law, as well as members of the Agricultural Insurance Pool, and insurers - agricultural commodity producers who operate in the territory of Ukraine and meet the criteria specified by the Cabinet of Ministers of Ukraine. A prerequisite for the provision of certain types of state support and subsidies to agricultural producers is the conclusion of an insurance contract for agricultural products.

In 2012, the state subsidized insurance premiums renewed but only under the contracts of winter crop sowing insurance; the government has decided to subsidize only standard cover insurance contracts. The state budget for 2012 provided 70 million UAH for these needs of producers. However, the conditions under which these funds were allocated did not facilitate their use. In order to compensate producers to September 15, 2012, they had to apply for insurance, but they could not meet this deadline and, as a result, lost their right of compensation. According to the results of the year, agricultural enterprises insured 727 thousand hectares of crops, paying 130.4 million UAH of insurance premiums, and received only 86 thousand UAH subsidies to compensate them. However, as before, insurance of agricultural crops was mostly carried out by farms that used commercial banks' lending services. So, according to the research, in 
2012 , with $5.1 \%$ of agricultural producers who insured crops, $4.8 \%$ were represented by those who did it for a loan; technical crops and vegetables insured solely for this purpose (Dobizha, 2013).

Since 2013 till now the state budget did not provide the allocation of funds to provide state support to agricultural producers in the form of compensation of insurance payments. During this period, with the general economic downturn, the agro-insurance market has shown a tendency of slowing down: the number of contracts concluded, the size of the insured area, the collected insurance premiums, and the average premium rate.

In the opinion of scientists, the main factors hindering the development of domestic agricultural insurance with state support are: the lack of systematic approaches to agricultural insurance with state support and the imperfection of the existing procedure for granting subsidies, in particular, the statutory period of their provision; non-compliance with the guarantees of full compensation of the established amount of subsidies; providing state support only in case of insurance of certain types of agricultural crops in accordance with the standard conditions for all regions.

Today, the level of insurance of agricultural crops in Ukraine is poorly developed and is only $2-3 \%$ of the total area planted. Instead, in countries where agro-insurance is integrated into the state risk management policy in agriculture (USA, Canada, Spain, Turkey, India), this indicator reaches $80-90 \%$. In Ukraine, this type of insurance is predominantly implemented as a mandatory element in certain government financial assistance programs for agricultural producers (for example, Agrarian Fund and State Food and Grain Corporation of Ukraine), according to which farmers can not obtain the necessary funding without insurance of their products. The use in Ukraine of classical insurance of crop protection as a way of minimizing agricultural risks is too weak and mostly formal. For the time being, agricultural commodity producers generally consider insurance not as a way of minimizing risks and preventing possible bankruptcy, but as additional unproductive costs that increase the cost of production.

The underdevelopment of the agro-insurance system leads to the fact that agricultural producers are forced to give up their profound specialization as an effective management mechanism and to diversify production risks by conducting several types of activities. At the same time, in order to ensure an adequate level of food security in a country, the state is forced to resort regularly to financial aid measures to the victims of agricultural production.

It is obvious that the current state of development of insurance of agricultural products does not correspond to its main task of managing risks in the agrarian sector in order to ensure the stability of agricultural production, sustainable and efficient development of the agricultural sector of the economy. This necessitates the introduction and development of a system that will provide a sufficient level of functional interaction between all major players in the agricultural insurance market agricultural producers, insurers and the state (Ukrainian Insurance Federation, 2018).

The state should play a special role in shaping the agricultural insurance market. The need for effective state regulation of the market, according to researchers, is related to the high degree of responsibility of each individual insurer for the socio-economic consequences of their activities (Gamankova, 2010, p. 13). The government has a significant role to play in consolidating the efforts of agricultural insurance stakeholders and balancing their interests. According to scientists, the Concept for the development of agri-insurance should be developed, which should give a boost and determine the strategic direction of the government's actions in this role (Shebanin and Kormyshkin, 2018, p. 9).

The modern model of state aid to agricultural producers is provided by the Law of Ukraine "On the Features of Insurance of Agricultural Products with State Support" (The Verkhovna Rada of Ukraine, 2012) was 
ineffective and needs to be reformed.

At the same time, as national and international experience shows that the state support for agricultural insurance has a stimulating effect on the development of the agricultural and insurance sectors, and also stimulates the growth of the economy as a whole. Without public support, such an acknowledged effective mechanism for risk management in agriculture as agri-insurance is still in place at the initial level of development in Ukraine.

We share the opinion of experts who argue that the construction of an effective model of state support for agricultural insurance necessitates: expansion of the concept of state support; changes in the procedure for providing financial assistance; the creation of a regulatory framework that would provide all insurers and insurers with equal access and equal opportunities in the agricultural insurance market. In particular, the draft law "On State Support for Agricultural Insurance" (The Verkhovna Rada of Ukraine, 2017), which is under consideration by the Verkhovna Rada of Ukraine, proposes to create the National Agricultural Insurance Agency as a specialized agency for managing agricultural risks. The effectiveness of the functioning of such an institution is confirmed by the experience of European countries, in particular Spain, Canada and the United States.

Insurance of agricultural production risks in the world is an important element of the system of financial and credit provision of agricultural producers. The system of agri-insurance is the regulator of the processes of socioeconomic development in the agrarian sector, its task is not only in protecting property at the time of the occurrence of an insured event and the reimbursement of direct damage, but also in eliminating the indirect losses that arose as a result of destruction or damage to property that is property or the subject of property rights of the insured. Thus, the purpose of insurance, as an effective regulator of the agricultural insurance system, is not only the protection of property, but also the provision of conditions for the harmonious development of the industry.

\section{Conclusions.}

Thus, the assessment of the development of agri-insurance in Ukraine suggests its significant dependence on the economic situation and the level of state support. In 2005-2008, insurance of agricultural crops was carried out with financial assistance from the state, which, despite of all its opacity, inefficiency and expense for agricultural producers, promoted the popularization of this type of insurance and played a positive role in protecting the interests of farmers. During 2009-2017 (with the exception of 2012), on the background of the general economic downturn, state budget funds were not allocated to support agricultural producers in the form of compensation for insurance payments. This led to a deterioration of the quantitative and qualitative indicators of the development of insurance of agricultural products.

In general, the use of classical insurance in Ukraine as a way of minimizing agricultural risks is too weak and mostly formal, and the agri-insurance market needs to improve state regulation, including the mechanisms for enforcing current legal acts, and systemic financial support from the state. Taking into account the complexity of the current financial situation of agricultural producers and the conditions for the formation of a market economy, the decisions of the government and the legislature in the field of agricultural insurance should be aimed at restoration of subsidization of a part of insurance premiums and other types of support, development of the Concept of development of agri-insurance, and also strengthening of the institutional component of this sphere of relations. A market model for the development of the agricultural insurance system in Ukraine should be based on the principles of public-private partnership. 


\section{References}

Accounting Chamber of Ukraine (2006), "On the effectiveness of the use of funds from the State Budget of Ukraine allocated for the development of the agro-industrial complex in 2005", available at: http://www.acrada.gov.ua/control/main/uk/publish/article/671040 (Accessed 23 February 2019).

Agrarian Union of Ukraine (2018), “Ukraine's agricultural insurance market: updated data on payments in 2017 and preliminary insurance data in 2018. Analytical study / Ministry of Agrarian Policy and Food of Ukraine in cooperation with the Project "Development of financing of agrarian sector in Europe and Central Asia". International Finance Corporation (IFC, World Bank Group)", available at: http://www.auu.org.ua/media/publications/529/files/Market\%20Survey\%20Report_2018 $04 \quad 13 \quad 1106 \quad 14$ 365993.pdf (Accessed 24 February 2019).

Aleskerova, Yu. V. (2014), "Improvement of state support for agricultural insurance”, Accounting and Finance, no. 4(66), pp. 96-102.

Bondarchuk, M. K. and Kondrat, I. Yu. (2014) "Peculiarities of agricultural insurance development in Ukraine based on the principles of public private partnership", The Scientific Bulletin of UNFU, vol. 24.1, pp. 182188.

Dobizha, N. V (2013), “Current status and problems of agricultural insurance in Ukraine”, Efektyvna ekonomika, no. 8, available at: http://nbuv.gov.ua/UJRN/efek_2013 8 41 (Accessed 24 February 2019).

Gamankova, O. O. (2010), "Ukrainian market of insurance services: its essence, tendency and the ways of its development”, Ph. D. Thesis, National economy, Kyiv National Economic University named after Vadym Hetman, Kyiv, Ukraine.

Liga: Zakon (2006), “To Europe with "a green box", available at: http://www.ligazakon.ua/news old/ga003510.html (Accessed 23 February 2019).

Lobova, O (2011), "The theoretical foundations of agricultural insurance”, Bulletin of Taras Shevchenko National University of Kyiv. Economics, no. 126, pp. 58-65.

Marych, K. (2017), “Agricultural insurance: concept, characteristics, types”, Visnyk Natsionalnoho universytetu "Lvivska politekhnika". Serie: yurydychni nauky : zbirnyk naukovykh prats, no. 865, pp. 405-412.

Melnychuk, Yu. M. and Slatvinskyi, M. A., (2018), "Organizational and legal bases of life insurance provision in Ukraine”, Economies' Horizons, no. 3(6), pp. 55-64, doi: https://doi.org/10.31499/26165236.3(6).2018.156316.

Petruk, T. Yu. (2017), “The economic content and significance of agricultural insurance”, Agrosvit, no. 4, pp. 4652.

Shebanin, V. and Kormyshkin, I. (2018), "Insurance - as a component of infrastructure providing agricultural enterprise development”, Ukrainian Black Sea region agrarian science, vol. 2, pp. 3-10.

The Verkhovna Rada of Ukraine (2004), The Law of Ukraine "About state support of agriculture of Ukraine", available at: http://zakon.rada.gov.ua/laws/show/1877-15 (Accessed 23 February 2019).

The Verkhovna Rada of Ukraine (2012), The Law of Ukraine "On peculiarities of insurance of agricultural products with state support”, available at: http://zakon.rada.gov.ua/laws/show/4391-17 (Accessed 08 February 2019).

The Verkhovna Rada of Ukraine (2017), Draft Law “On State Support for Agricultural Insurance”, available at: http://w1.c1.rada.gov.ua/pls/zweb2/webproc4 1?pf3511=61709 (Accessed 30 February 2019).

Ukrainian Insurance Federation (2018), "Creation of an agricultural product insurance system with state support", available at: http://ufu.org.ua/ua/about/activities/strategic initiatives/4958 (Accessed 23 February 2019).

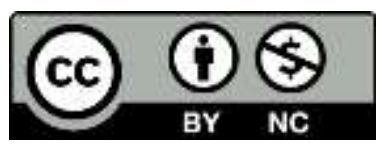

Цей твір ліцензовано на умовах Ліцензії Creative Commons «/з Зазначенням Авторства - Некомерційна 4.0 Міжнародна» (CC BY-NC 4.0).

This is an open access journal and all published articles are licensed under a Creative Commons "Attribution-NonCommercial 4.0 International" (CC BY-NC 4.0). 